\title{
A pásztorok tudásának és világnézetének szerepe a biodiverzitás és az ökoszisztéma-szolgáltatások fenntartásában
}

\author{
Kis József ${ }^{1}$, Barta Sándor², Elekes Lajos³, Engi László4, Fegyver \\ Tibor $^{5}$, Kecskeméti József $^{6}$, Lajkó Levente ${ }^{7}$ és Szabó János ${ }^{8}$ \\ ${ }^{1}$ gulyás, 6625 Fábiánsebestyén, Rózsa Ferenc utca 30. \\ ${ }^{2}$ gulyás, 5321 Kunmadaras, Széchenyi u. 7. \\ 3'gulyás, 6767 Ópusztaszer, Rontó szél 173. \\ ${ }^{4}$ gulyás, 6728 Szeged, Gyula u. 16. \\ ${ }^{5}$ gulyás, 6900 Makó, Járandó u. 14/1. \\ ${ }^{6}$ juhász,6097 Kunadacs, Peregadacs u. 3. \\ 7 juhász, 6794 Üllés, Sipos malom 42. \\ 8juhász, 4002 Debrecen, Nagy Mihály kert 71. \\ e-mail:jozsefkis82@gmail.com
}

\begin{abstract}
Összefoglaló: A pásztoroló legeltetés és a természetvédelem egymásra utaltsága egyre nyilvánvalóbb. A pásztorok jól ismerik a körülöttük lévő élővilágot, az évszázados gyökerekkel bíró pásztortudományt őseiktől, szüleiktől, valamint saját tapasztalataik útján tanulták. Pásztorként hét pásztort kérdeztem a legelőhöz, legeltetéshez kapcsolódó tudásukról, elsősorban homoki, löszös és szikes területeken legeltető pásztorokat. Az eredmények jól mutatják, hogy a pásztorok gyakran otthonuknak tekintik a természetet, a legeltetés szakaszolásával, egyes területek kímélésével, megfelelő napszaki és évszaki beosztással olyan módon tudják irányítani, befolyásolni a legeltetés menetét, hogy közben hosszú távon megőrzik, esetenként fokozzák a legelőterületeik termőképességét. Hatékonyan tudják regenerálni az elavarosodott, elnádasodott területeket is. E legelőkezeléseknek nagy szerepe van a biodiverzitás megörzésében is. Azon természetvédelmi szakembereknek és kutatóknak szól írásunk, akik szeretnék jobban megismerni, hogy a hagyományos ökológiai tudással rendelkező pásztoroknak mi lehet a szerepe a „működő” természet fenntartásában. Ahogy egy pásztor fogalmazta: az élövilágnak is van egy körforgása, amihez szükségeltetik a jószág.
\end{abstract}

Kulcsszavak: pásztoroló legeltetés, szakaszoló legeltetés, természetvédelmi kezelés, hagyományos ökológiai tudás, pásztortudomány 


\section{Bevezetés}

Napjainkra egyértelművé vált, hogy a hagyományos, extenzív gazdálkodás, közte a pásztorok fenntartható legelőhasználata a biodiverzitás számos eleme számára létfontosságú (Báldi et al. 2013, UNESCO-IPBES 2013, Varga et al. 2016). A legelés alól felhagyott területeken cserjék, pionír erdők és inváziós fajok szoríthatják ki a védendő növény- és állatfajokat (Haraszthy 2014). A hagyományos gazdálkodási módok felhagyása miatt egyre több terület lesz kihasználatlan, kezeletlen. A természetvédelmi szempontból hasznos extenzív gyephasználati módok fenntartása és támogatása a fentiek miatt is fontos természetvédelmi cél (Babai et al. 2015). A természetvédelemnek egyre inkább érdemes a helyi emberek, a mai gazdák tapasztalataira, motivációira építenie (Mapinduzi et al. 2003, de Snoo et al. 2013, Varga \& Molnár 2014, Babai et al. 2015). Természetvédelmi kezelések tervezésekor a hagyományos, tapasztalati tudás gyakran sajnos háttérbe szorul a tudományos kutatások analitikai módszereken alapuló eredményeivel szemben. Pedig e két tudásrendszernek, a két különböző logikai síkon eredményeket mutató és értéket teremtő tevékenységnek inkább ki kellene egészítenie egymást (vö. Kis 2011b, Babai et al. 2015, Molnár et al. 2016).

A hagyományos gyephasználat részleteinek jobb megismerése segíti, hogy e használati módok hatékonyan segítsék a természetvédelmi kezelést (Molnár 2014, Babai et al. 2015). A hagyomány ugyanis nem pusztán a múlt, a régvolt emberek mára sokszor elfelejtett, részben el is avult tudása (Bellon 1996, Kunkovács 2013). A hagyomány velünk él. A jelentős természeti értékü gyepeket legeltető pásztorok tudásának nagy része ugyan ősi eredetủ (Molnár 2012), e tudást azonban használóik folyamatosan a jelenhez adaptálják (Kis 2011 a, b, Meuret \& Provenza 2014). E tudás a biodiverzitás és számos ökoszisztéma-szolgáltatás fennmaradását is segíti (Heikkinen et al. 2012, Vadász et al. 2016).

Ezt a tanulmányt pásztorok írták. Azokat a tapasztalatokat gyüjtöttük össze, amellyel hasznosítjuk, megőrizzük vagy éppenséggel javítjuk legelőink fütermő képességét, regeneráljuk a felhagyott területeket, illetve azokat, amelyek nem voltak megfelelő módon használva. Bemutatjuk, mit tapasztaltunk a legeltetés élővilágra gyakorolt hatásai kapcsán.

Ne felejtsük: az emberek beavatkozása előtt a vadon élő legelő állatok ugyanúgy letették a névjegyüket erdőn és mezőn, mint ma az ember által legeltetett állatok (Németh 2016). 


\section{Módszerek}

A tanulmány első szerzője (maga is pásztor) 2016 februárjában hét pásztorral készített interjút. A pásztorok az ország más-más részén, különféle élőhelytípusokon legeltetnek. Több olyan kérdést tett fel nekik, amelyek szorosan kapcsolódnak a munkájukhoz. A 12 órányi rögzített hanganyagot szóról szóra írásban dokumentálta, majd személyenként szétosztotta témakörök szerint. A pásztorok gondolatait, eredeti idézeteiket dőlt betű jelzi. Állóbetűs szavak segítik a jobb érthetőséget. A ferde vonalak az egyes pásztorok idézeteit választják el egymástól.

A megkérdezett pásztorok zöme szikes és homokos területeken legeltet Magyarország keleti régiójában. Vannak, akik szikes és löszös pusztákat legeltetnek, emellett mocsaras területeket is hasznosítanak, kezelnek. A homokos részeken élők szántókon, tarlókon, ugarokon és erdőkben egészítik ki a takarmányszükségletet. Az egyik megkérdezett pásztor a dunántúli régióban, dombvidéken is legeltetett. A homokos területek földrajzilag a Duna-Tisza közén helyezkednek el a Kiskunsági Nemzeti Park müködési területén (pl. Kunadacs, Üllés). A szikes, löszös, mocsaras legelök a Hortobágyi Nemzeti Park, valamint a Körös-Maros Nemzeti Park (pl. a Csanádi-puszták) területén találhatók. Kunmadaras környéke UNESCO bioszféra magterület.

\section{Eredmények és megvitatásuk}

\section{Mit jelent egy mai pásztornak a természet?}

„Ez olyan, mint az otthon, ezt nem lehet elmondani. Ezt érezni kell! Tavasszal, mán az ember mikor kimegy, beleszagol a friss levegöbe, azt nem lehet elmondani azt az érzést, hogy milyen." (Barta Sándor, gulyás)

A pásztorok természethez füződő viszonya nem olyan, mint az átlagembereké. A többség a gyermekéveit is a természet közelségében töltötte valamilyen módon. Vannak, akik szintén pásztor szüleik, nagyszüleik mellett. Így a természet felnőtt korukra is nagyon sokat jelent számukra. E nélkül nem is tudnám elképzelni. Én inkább a múltba' élek, a múltat a természeten és a pusztán keresztül tudom elképzelni. A jószággal, a madárral, a növényvilággal, az érzelemmel, az illattal. / Gyakorlatilag ott nöttem fel, én azt az életet, én ott szoktam meg. / Mindig is természetközelben éltem az életem. Nekem sokat számit, mer' ha nem tudnék itt kinn lenni a természetbe', akkor valószínüleg megbuggyannék. / Én gyerekkorom 
óta tanyán élek, nekem az állattartás, a természet nagyon szorosan kapcsolódik egymáshoz.

Sokan a természetet az otthonuknak nevezik. Jóformán azt mondom, az az otthonom inkább. / Ez olyan, mint az otthon, ezt nem lehet elmondani. Mindazok ellenére, hogy a pásztoroknak a természet a munkahelyük, mégis a kikapcsolódást, a pihenést, a felüdülést is látják benne. Megnyugtat. Jól érzem magam benne. / A természet az nekem megnyugvás. / Nekem ez jelenti a kikapcsolódást. Van, aki így fogalmazott: A természet énnálam egy szanatórium. A pásztorok egytől-egyig kerülik a várost, inkább a természetet választják. Még akkor is, ha az időjárás viszontagságaival kell szembenézniük. A szabadságot jelenti, a város zajától távol. / Ott éreztem mindig jól magam, nem a város közepén. / Akármilyen idő van, legeltetni köll. Ha esik az esö, ha süt a nap, akkor is kinn vagyok.

A természet iránti tiszteletük és alázatuk abból is fakad, hogy a megélhetésüket adja a legelő. Ebből tudják eltartani a családjukat, ezért vigyáznak is rá, amenynyire csak tölük telik. A megélhetésünk. Azt úgy kell csinálnunk, hogy tudjunk belöle profitálni, mert ha nem tudunk profitálni, nincs mibül élni. / A családomnak a megélhetésit adja. Nagyon ki vagyunk mi téve a természetnek. Megérzi a családom is, mer'akkor (nagy aszályban) kevesebb lóvé megy haza. Ha van egy aszályos időszak, nem úgy üzödik (vemhesül) a birka, nem lesz annyi ikerellés. Sőt! Egyesek minden, a természet rendjére ható káros tényezőt kiiktatnának, ha lehetne. A hangok, amit ott hallok hangot, még a repülöt is lehúznám juhászkampóval, csak ne zörögjön fent.

A pásztorok ma jellemzően nem vallásos emberek, de mégis sokszor látják Istent a dolgok, a történések háttere mögött. Nem vagyok vallásos ember, de valamilyen szinten a Teremtöt jelenti (a természet). Úgy gondolom, mi ebben csak résztvevők vagyunk. Szolgák. Valakinek irányitani kell, hogy az a kisbárány megszülessen, felnőjön. Hogy meg tud újulni a növényzet, ki tud hajtani, ha vizet kap. Valami ilyesmi.

Ha egy szóval kell jellemezniük, hogy mit jelent nekik a természet, a legtöbb pásztorembertől ilyen válaszokat kapunk: Mindent! / A szabadságot! / Kikapcsolódást!

\section{A mai pásztorok szüllei, nagyszülei és az akkori természet}

„, Annak idejin, mikor gyerek vótam, oszt apám gulyás vót, kinn vótunk. De hát ott úgy müködött, vót csúzlija, meglütte azt a kis nyulat, fácánt. Fözött. Így müködött az egész, ez hozzátartozott a pásztorsághoz." (Fegyver Tibor, gulyás) 
A pásztorok zöme úgy véli, hogy a természet ugyanazt jelentette az őseinek is, mint neki. Majdhogynem egy ugyanaz. / Nagyapám is gulyáskodott. A természet ugyanúgy az öregnek is azt jelenti mint nekem. / Szerintem nálunk, akik jószággal foglalkozunk, olyan nagy különbség nincsen.

Valamiben mégis más volt a kapcsolat, hogy nekik valahogy másképp jelentette a megélhetést, mint nekem. Egyik oldalról az ember és természet kapcsolatában vélnek felfedezni különbséget. Most egyre kevésbé van az állatnak élöhelye, mert egyre jobban belelépünk (a természetbe). / Az én nagyapám pásztor vót, és sokat emlékszek rá, hogy az öreg milyen alázattal beszélt a pusztáról, hogy maga a pusztának köszönheti a létit, a munkáját. / A nagyszüleink együtt éltek a természettel még. Nekik majdhogynem a részük volt abba'az idöbe'. / Nekik többet jelentett, mer'a megélhetésüket, tényleg az életüket jelentette. A megélhetésen nem csak azt értik, hogy a legelö növényzetén múlott a gazdaság léte, hanem azt, hogy az ember a pusztába' megtanálta azt is, amit egyen. Részei voltak az életközösségnek, a táplálékláncnak.

Másik oldalról a biodiverzitásban látnak különbséget. Nagyapámnak természetes vót minden olyan növény vagy állat, ami most nincs, vagy ritkán van. Most kell védeni mindenféle növényt, állatot. Most meg kell határozni az eszmei értékét neki, hogy egyáltalán megmaradjon mutatóba. / Hát, szerintem sokkal több madár vót, sokkal több jószág vót.

Utalást tesznek még a modernizációra is. Nem vót régen ennyi ház, nem vót régen ennyi út, nem vót régen ennyire kiterjesztett minden. / Mer 'még akkor érintetlen volt, nem volt még itten villanypásztor. / Ugyanazokkal a problémákkal nézünk szembe, csak mi mondjuk egy kicsit mán korszerübben próbáljuk csinálni, mint ök csinálták. Mi jobban hagyatkozunk már a tudományos dolgokra. Ök meg, amit megtapasztaltak, amit egymástul hallottak, abbúl tudtak épitkezni.

Bármelyik oldaláról is nézzük a dolgot, egy valami biztos: még az ösöknek a természet az nem ez a természet vót, ami nekünk van. Mink mán szerintem csak nyalogassuk azt a fajtát.

\section{A fö ökoszisztéma-szolgáltatás, a legelöfü használata, adagolása, beosztása}

„A marha menne majd a jóra egybül, de rákormányozom arra, hogy úgy szépen faljatok egy kicsit itten, mer' ugye ez is hozzátartozik a pusztához, meg ettül nincs bajotok, csak nem annyira szeretitek." (Elekes Lajos, gulyás)

A legelőkön termő növényi biomassza-mennyiségét leginkább az adott esztendő időjárási viszonyai határozzák meg. Minden évben van olyan időjárási ok, ami miatt a legelő biomasszája kisebb a potenciálisnál. Ezért talán a legfontosabb 
szempont a legelők beosztásánál, hogy elég legyen év végéig, mer'ugye azt a legeltetési idöszakot ki kell ott húzni. Nagyon fontos a pásztornak az állataik jóléte, mert azon múlik, mennyit tudnak termelni. Mindig az a szempont, hogy tartsam jól a marhát, a lehetöséghez képest a legjobban. Mer' nyilvánvaló, hogy azér' vagyok pásztor, hogy az én kezem alatt jó legyen a marha (kondíciója). Viszont tudjam beosztani azt a területet. Ehhez viszont jó minőségü, tápláló növényekre van szükség. Mindig a legjobbat keresni nekik, télen már megeszi a savanyú füvet is, mert jobbat nem talál.

A pásztorok jól ismerik az egyes növényfajok sajátosságait. Megnézem, hogy elöször is milyen növényekkel van benépesülve a legelö. / Minden idöszaknak megvan a megfelelö füje, ami akkor jó, ami akkor hasznos. Tehát a napi, havi, évi legeltetési rend során igazodnak a vegetáció összetételéhez, térbeli és időbeli felhasználásának lehetőségeihez is.

A használatot úgy irányítják, hogy biztosítsák állataiknak a változatos étrendet, valamint a legelő számára is biztosítsák a változatos és fokozatos terhelést. $M i$ kor mán láttam, hogy nem úgy legel a jószág rajta, unja, akkor fogtam magam, átmentem a másik területre. És mindig igyekeztem váltogatni a legelöket. / Körbelegeltettük a szílit. Aztán a közepit végigjárattuk, utána megterítettünk (hagyták a jószágállományt kedvük szerint szétterülni a területen), oszt ott legelt, ahun akart, de elötte meg szakaszosan legeltettünk. Beosztottuk ezzel a szakaszos legeltetéssel. A szakaszos legeltetés kivitelezéséhez azok, akik kis területen gazdálkodnak, előnyben részesítik a villanypásztort vagy a legelőkertet. Előnyösebb a legelökert. Ha van 8-10 legelökerted, olyan szépen be lehet osztani. A keritéses azért jó, mert akkor legel a birka amikor ö akar, minden csücsköt kilegel. / Nem az egészet járja körbe a jószág, csak azt az egy adott szakaszt, ami ki van neki szakaszolva. Amit két hétig legelt, másik két hét múlva átmegy a másik ódalára, nem rágja teljesen le. Tud regenerálódni az a terület. / Esetleg szakaszos legeltetésre jó a villanypásztor. Leszakaszolja a legelöt az ember, és akkor szakaszonként adagolja.

Nem csak éves, hanem napi szinten is változatosan legeltetnek. Meg nekem mindig aszonta apám, hogy délelött kopogó, délután csattogó (a kopogó száraz füves terület, a csattogó vizes mocsaras). Tehát délelőtt legeltetjük a szárazat. Ha délelött jóllakatod, az mán délután csak nyalakszik, oszt el szoktuk csapni nádas részekbe, mer' akkor mán jobban megáll benne mint éhesen. / Ha a marhára bízom, akkor az a javát keresi majd. Ha megette a javát, marad a hitványabb, azt meg nem legeli. Reggel, mikor kihajtok, próbálok ezért szépen, nem nyomva a marhát, de abba az irányba irányitani, amerre én szeretnék velük menni.

Jellemző, hogy az állattartó telepek, pihenő és éjszakázó helyektől való távolság szerint is beosztják a legelőket. Az állatok napi és évszakos ritmusához, az évszak sajátosságaihoz igazodva, akkor mán délbe'nem állítom be (a delelőhelyre 
pihenni). Az év közepére, akkor érek el a legmesszebbi pontra. / Eleibe inkább elmegyek messzebb, és amikor már fogy a legelö, begyünnek a melegek, akkor itt próbálok a tanya körül lenni. Az állatok, föként a juhok biológiai ciklusához is igazodnak. A közelebbi legelöket szoktam elletésre hagyni, a hodály környéki legelöket. Föleg a hasas állatokkal szoktam a legjavát legeltetni. / Próbálom az ellési idöszakra tartalékolni azokat a helyeket, amik lehetöleg közel vannak a tanyához, ne kelljen messzirül behordani a bárányt. De ennek hátterében is az állatok jóléte az elsődleges szempont, mivel az állattartó telepek környékén tápanyagdúsabb a talaj, táplálóbb növények nőnek rajta. A hodály környéke meg mindig a fiasnak, a bárányos juhnak szoktam meghagyni. Ezzel kedveznek a fias állatoknak, ugyanakkor az épületek közelsége védelmet nyújt az időjárási viszontagságokkal szemben is. Próbálom a legeltetést úgy csinálni, hogy korábban kimenni, és általában már 8-9-kor meglegeltetni üket, mer'8 óra körül már kezd összeállni a birka (egy csomóba) a meleg miatt.

Összefoglalva: a legelők beosztásának elsődleges szempontja, hogy kitartson a legeltetési szezon végéig. Ezután az állatok jóléte, a legelő kímélése, valamint a pásztor saját és állatainak kényelme a mérvadó. Van még egy szempont, ami napjainkra egyre fontosabbá válik: a természetvédelem. Az egyik megkérdezett pásztor, aki természetvédelmi területen dolgozik, egy teljes természetvédelmi célú legeltetési rendszert írt le (lásd a szövegdobozt).

\section{Az ökoszisztéma-szolgáltatás állapotának fenntartása: a legelö védelme}

„Próbálom ugyanúgy csinálni, ahogy apámtúl láttam. Én azt jónak tartottam, igy visszagondolva rá, jó megoldás volt. Ameddig csak tudta, kímélte a legelöt." (Kecskeméti József, juhász)

Egy pásztor számára nagyon fontos, hogy minél jobban csökkentse a legelö terheltségét. Azt tudni kell, hogy mennyi jószágot vállal rá az ember. Ne legyen túllegeltetve. Ügyelnek rá, hogy lehetőség szerint megfelelő állatlétszám legyen a területen. A legeltetési idény időtartamával is próbálják csökkenteni a terhelést. A régi öregek nem vótak ám bolondok, hogy Szent György napkor ki, Szent Mihálykor meg haza. Ha Mihály napkor hazahajtana az ember, akkor lenne öszi mezö. Tavasszal abba 'az avarba 'hamarabb mozdulna a mezö, mint amikor összel födig le van nyalatva. Az őszi-téli legeltetés nem kíméli annyira a legelőt, mert már nincs ideje a növényeknek a megújulásra. A hosszú távú fenntartás viszont nagyon fontos számukra. Mindig úgy próbálunk közlekedni a jószággal, hogy ne vágassuk fel ahun szikesebb, föleg meg szikpadkás. / Mindig a távolabb esö legelöket szoktam járatni, és sávonként hazajárni a juhval. Odafigyelnek arra, hogy 


\section{Tudatos természetvédelmi célú ökoszisztéma-szolgáltatás kihasználás,} pásztor módra: legeltetés virágzás után, virágzás előtt vagy éppen az előző év őszén:

Van a Királyhegyesi-pusztán a Liliomos nevü mocsár. Ott elegáns kosbor (pompás kosbor, Orchis laxiflora subsp. elegans) nö. Az június 15-re elvirágzik. Mivel a csenkeszes, ürmös, padkás rész viszonylag gyorsan ki szokott száradni, elöször kihajtáskor, április végén-május elején lelegeltessük ezt az ürmös csenkeszes területet. Egészen addig húzzuk ott az idöt, amíg június 15-e el nem telik. Addigra elnyílik az összes kosbor. Megvárjuk a virágzást, és utána megyünk bele ebbe a területbe, mer' akkor már a felnövö növényzet bezárul, elfedi a következö nemzedéknek a termöhelyét. Ezért jó alaposan megrágatjuk a mocsárnak azt a szélét, ahol a kosborok nönek, és a következö évben sokkal több virág fog nöni. Annak köszönhetöen, hogy kirágattuk a területet.

A szomszédos magasabb térszinteken nagyon erös vetövirág (Sternbergia colchiciflora) állományunk szokott lenni. Az meg augusztus közepén szokott nyílni. Ezeket a széleket a csenkeszes ürmös, padkás részekkel egyidőben június 15-re lejárjuk, leszedjük róla az összes növényt, amit csak lehet. Június 15-e után ezeket a magasabb térszinteken lévő területeket, löszgyepeket, mentesitjük a marhától, hogy utána az alig néhány centiméteres vetővirág tudjon virágozni. Nem lesznek széttaposva a virágok, gyönyörüen tudnak hajtani kifelé.

A tavaszi héricses (Adonis vernalis) termőhelyeket meg összel legeltetjük le, mikor már lassul a növénynek a fejlödése. Augusztus közepétöl szeptember végéig leszedjük róla a füvet. Így tavaszra egy alacsonyabb füszintet tudunk biztositani a héricseknek.

A legeltetést összeegyeztetjük azokon a pusztákon, ahol olyan növények vannak, amiket védeni kell. Most ezeknek köszönhetöen nö a vetövirág állomány. Az elegáns kosbor pár évvel ezelött még alig volt, most két évvel később 300 tö környékén volt a legeltetésnek köszönhetöen. Ugyanúgy a hérics is néhány száz töröl felment közel 3000 töre, szintén a legeltetésnek köszönhetöen. Tehát így lehet ütemezni. Attól függ, hogy milyen virág, megnézed, hogy mikor nyilik, és vagy elötte vagy utána lévö idöszakban ráviszed a termöhelyekre a jószágot. Jó alaposan megjáratod, lelegelteted, vagy letapostatod. Utána annak a virágnak jobb lesz.(Engi László) 
ne okozzanak taposási kárt. Az állandóan járt útvonalakon hamar kipusztul a növényzet, esős időben a fellazult talajon járva még inkább.

A pásztorok igazodnak ahhoz is, hogy az időjárási viszonyok milyen legeltetést tesznek lehetővé az egyes legelőtípusok esetében. Azt is nézem, hogy hun van a szikesebb, hun van a vizenyösebb, nézem azt, hogy esö mennyi volt, meg mély nyomokat, ha egy mód van rá, ne hagyjak a pusztába'. De amikor nagy szárazság van, akkor meg szeretek velük lemenni arra a részre, ahun nádas, gyékényes, zsiókás, föleg a korai idöszakokba. A másik dolog az, hogy vannak olyan füfélék, amiket a nagy melegbe' nem eszik meg a jószág, csak letapossa, de harmattal le van puhulva, és megeszi. A taposási kár úgy is csökkenthetö, hogy mindig más iránybúl engedjük az állásra, ha nagyon vizes a terület.

Nem csak esős időszakban, hanem szárazság idején is tudnak ártani a legelönek. Egyrészt az elszáradt növények letörnek az állatok lába alatt, így nem legeli le őket az állat. Az a növény akkor már nem hoz hasznot sem, és sérül is. Másrészt szintén ki tud pusztulni a növényzet a nagyon tiport, tömörödött talajon. Igyekeznek a károkat csökkenteni. Nem járok ugyanazon a részen napokon keresztül. Köll egy-két harmat, amitöl megfrissül a legelö. Itt nincs az, hogy teljesen a földig lerágatom, mert nem is legel.

A villanypásztor használatát csak bizonyos esetekben fogadják el. Ha nincs más lehetöség villanypásztorral meg lehet oldani. / A személyes kontakt a jószággal nagyon fontos. A villanypásztoros legeltetést, azt akkor tudom elfogadni, amikor nagyon szükek a mezsgyehatárok. Ha jó pásztor van jó kutyákkal, akkor semmi jelentösége nincs a villanypásztornak. / Ha ilyen kis csip-csup födek vannak, nem tudod megállítani rajta a marhát, mer'az eleje benne van, a hátulja meg leér rúla. A túllegeltetés és a taposási kár problémája megjelenik a villanypásztorban magára hagyott jószágok esetében is. A villanypásztoros legeltetésnél nincs koordinálva a villanypásztoron belül a jószág. Ha megszokott a marha egy bizonyos helyen, akkor ott tapossa ki. / Hajlamos a birge túllegelni bizonyos részeit a legelönek. Valahol nagyon szeret legelni, és ha már nincs rajta semmi, akkor is ott áll meg. A villanypásztorral szemben a pásztor az tudja, hogy ha most ez a terület fölázott vagy laza vagy ne legeltessem túl, mer' mán ott épp elég. / A pásztoroló legeltetéssel, akkor és oda kell mennie, ahova hajtod, azt kell legelnie, nem csak a javát kiszedi, a többit meg legázolja.

A pásztorok törekednek a folyamatos megújulás biztosítására, a fühozam minőségi és mennyiségi állandó szinten tartására. Azt olyan módon kell, hogy az le is legyen takaritva, és a jószág se legyen rossz. Nem kell túl csupaszra rágatni, hogy az utósarjadását meg tudja indítani. Szépen szakaszosan legeltetem a területet, s mire visszakerülök, addigra sarjadás van újra. / Igazából próbálok arra töre- 
kedni, hogy egy bizonyos területet két-három naponta szoktam legeltetni, tehát mindig másfele megyek.

A legelőterületek fenntartásánál a terület eltartóképességének megfelelő állatlétszám betartásán túl a felesleges mechanikai terhelések minimalizálása is fontos szempont.

\section{Milyen tényezők játszanak szerepet a legelö fütermő képességének leromlásában?}

„Ha mindig, egyfolytába' egy területet legeltet, úgy kiéli, hogy azok a növények szaporodnak el rajta, amiket nem eszik meg a birka. Az föl tud magvadzani, el tudja szórni a magját." (Lajkó Levente, juhász)

Magyarország extenzív állattartásra alkalmas vidékein rengeteg a kihasználatlan terület $\mathrm{A}$ megkérdezett pásztorok mindegyike így válaszol elsőként a feltett kérdésre: Legjobban akkor megy tönkre a legelö, akkor vadul el, ha nincs rajta jószág. I Tönkre tud menni akkor is, ha szabadjára hagyom a pusztát, és nem kezelem, nem is legeltetem. / Ha nincsen rendesen legeltetve, akkor elgazosodik. / Huszonakárhány éves madarász tapasztalatom folyamatosan azt mutatja, hogy nagyon sok madárfaj azért tünt el az országból, meg nagyon sok növényfaj is azért tünt el, mert fölnövényesednek a területek. A pásztorok tehát elsődlegesen abban látják a legelök tönkremenetelének okát, ha nincsenek legelő állatokkal karbantartva, így a felnövő gyomok elnyomják a hasznos növényzetet. Gyönnek a tüskök, és a tüsköket nagy üzemanyagáron, drága gépekkel kaszálják. Ha a jószág időbe' ott van, amikor még gyenge az a bizonyos tüsök, megenné. Mikor kivágja a bugáját, meg mán magvadzik, bizony, nem nyúl hozzá egyik se. / A homoktalajok nagyon ki tudnak hevesedni, ha nincsenek legeltetve. Akár a parlagfü, akár a vaddohány elszaporodik benne, úgy kihevesiti a homokot, hogy utána évekig akármennyi esö esik, nem tud bevizesedni, mer'lefolyik rúla.

A leromlás másik említett oka a túllegeltetés. A rengeteg agyonlegeltetés. Nem olyan a fühozama neki következö évben, mint amikor van hagyva pihentetve. / Ha krónikusan túl van legeltetve. / Meg hogy ha esetleg agyon van járatva, akkor is tönkre megyen. / Attól, hogy nem hagyják megújúlni. Ráadásul a legelö kapacitásán fölüli állatlétszám van rajta. A túl sok jószág, a túllegeltetés kiéli a területet, ha nincs hagyva pihenni, akkor nem is tud regenerálódni, mer' nincs ideje rá. A túllegeltetés kapcsán a villanypásztoros legeltetés is szóba került. A növényzet szempontjából is jobb, ha mindig meg tud újulni az a terület. Ha mindig rágatva van, akkor csak bizonyos növények szaporodnak el. Azok, amiket nem szeret a birka, fel tudnak magvadzani, és akkor fertözödik a legelö. 
Leromlást okozhatnak a csapadékos időszakok is. Esős időbe', akkor kárt is tesz benne. Kitapossa, kijárja belöle még a haszonmezöt is. / Ha nagy sáros idöben egy csapáson járassák, avval is szitveri a mezöt (a legelő növényzetét), de itt már emberi tényezö, a pásztor tudománya is sokat számít. A pusztának a tönkremenetelét még keresem abban, hogy a nem megfelelö legeltetés, a nem megfeleló ember. Az emberi tényező kapcsán a törvényi szabályozások átgondolatlanságát is érdemes megemlíteni. Kik hogyan állnak hozzá, kik azok, akik akadályozzák a dolgokat. A tájvédelmi szakemberek azok, akik létrehoznak bizonyos törvényeket.

Összegezve, három nagy tényezőt látnak a pásztorok a legelők tönkremenetelében. Ha nem járja a jószág. / Túllegeltetés, mindig ugyanoda hajtják. / Meg hogy ha esős időbe' járassák. Elekes Lajos gondolatai néhány mondatban foglalják öszsze a legelők tönkremenetelének problémáját: „A magára hagyás is halálát tudja okozni egy jó pusztának. A pusztát is lehet kezelni, elöre masszírozni. Jobb, mint hogy utólag rokkanttá tenni. Ezzel megint aláirjuk a pusztának a halálát. Akkor lehet mondani azt, hogy amit ránk hagytak az ösök, mink hagytuk tönkremenni."

\section{A leromlott legelők regenerálása}

„Ha egy elvadult területre mentem, az akkor még saláta vót. De miután legelt rajta az állat, megtrágyázta. Tápanyagot kapott az a terület, az a növényzet, akkor az úgy kezdett szépen finoman a salátábúl átváltani rántott hússá annak az állatnak." (Szabó János, juhász)

Előfordulnak olyan esetek, amikor a pásztorok elhagyott, elhanyagolt, felgyomosodott területre kerülnek állataikkal. Ilyenkor sok esetben nem csak egyszeri kezelésre van szükség, hanem akár hosszú éveken át kezelik a területet, hogy az ismét megfelelö állapotba kerüljön. Az ilyen területek legeltetése kapcsán rengeteg tapasztalatra tettek szert.

Az alaphelyzet, hogy az elvadult részeket nem kedvelte, nem legelt úgy az állat. Feljebb nött a fü annyira, abból ki is forgott. Nagyon nehezen lehetett rákapatni arra, vagy le kellett szárzúzózni, hogy egyáltalán az állat belemenjen. A magasra növő, elöregedett, vastag, kemény szárú növényeket nem kedvelik az állatok. Volt, ahol nem is látszódtak ki belüle az aprajai. / Legelöször a rózsabokroktól, meg a szederindától kellett leszárzúzózni, hogy egyáltalán valamit tudjunk vele kezdeni. Az ilyen területeken, amit nem eszik meg avast, azt a taposásával megtöri. / A száraz gazt úgy törettük le a marhákkal. Csak törik és tiporják ezeket a részeket. Az öreg avas nádat kitörték a marhák, összezúzták, széttaposták, és helyette már csak sarjúnád van (amit szeretnek). / Letapossa a marha, az is azt keresi, a gyenge zödet. Keresik az aljnövényzetben megbújó zsenge füveket. Szívesen ma- 
rad mindaddig, amíg talál a gaz közt gyenge zöldet. Az ilyen területek kezelésbe vételekor tehát az első mozzanat, hogy míg a nem kivánatos növények vannak, addig törjék, szaggassák a jószágok. Akkor tud igazán regenerálódni a terület. Miután le lett tapostatva, zúzva a felnőtt növényzet, minöségre is volt változás, mer' egyrészt az állat megtrágyázta, a másik meg az, hogy legelt rajta. Akkor már a fü is jobban nött rajta, tápanyagdúsabb volt, mint annak elötte. Jobban jóllakott rajta, tartalmasabb volt az állatnak. / A füfélék, azok olyan bársonyszönyegszerüen kezdtek visszaépülni. Következö évben tisztább pusztát kaptál vissza, és jobb minöséggel, mer'teret kaptak azok a füfélék, akik egyébként el voltak nyomva. A változás egyértelmú a pásztorok szerint: sokkal diverzebbek és tisztábbak lettek azok a területek, amelyeket legeltetésbe vontak.

Természetvédelmi szempontból sem elhanyagolható az eredmény. Királyhegyesen a Liliomos mocsár is ilyen volt. Soha (értsd: emberemlékezet óta) nem volt legeltetve. Most gyönyörüen változik. Amig a nagy mocsáron legeltettünk, három év alatt ezt a két méteres gyékényest az utolsó szálig mind eltüntették, kiirtották. Körülbelül 5-6 méterrel visszaszorult a széle a nádasnak., ahogy kitaposták a marhák. A kosborok semmiröl nöttek fel több száz töre. A legeltetés hatására sokkal tisztább, mindig frissül felfele a legelö. / Ha marha van ráengedve állandóan, $a z$ be fog állni elöbb- utóbb (a legelö növényzete be fog állni egy állandó szintre). Szarja a marha, tapossa, csipkedi, rágja. Énnekem ez a meglátásom, akkor tisztul a legelö.

A legelés mellett nagy hatással van az állatok trágyája is a növényzetre. Meghugyozza, megszarja, akkor kiéli, úgy látszik. De meg kell nézni egy hónap múlva, hogy néz ki a terület. Olyan haragoszöld, hogy össze se lehet hasonlítani a többivel.

Fontos, hogy ezeknek a területeknek a kezelését is tudatosan, előre tervezve lehet a leghatékonyabban végrehajtani. Vót olyan esztendö, hogy hamarébb viszszatértünk rá, mint ahogy szoktunk. Sokkal jobb eredmény vót. Csak akkor is tudni kell, hogy na, ne tovább! Megfelelö jószággal, megfelelö ideig legeltetni, és megfelelö hozzáértéssel.

Egyes esetekben még a villanypásztor alkalmazását is célszerünek látják a legelö feljavítása során. Viszont ha már arról van szó, hogy be kell menni a zsombékba, három méteres nádasba, amit úgysem fogsz látni, akkor ott a villanypásztor a célszerü., mer' ember az nem tud utánamenni a jószágnak ilyen körülmények között.

Többféle állatfaj egyidejű alkalmazását is többen előnyben részesítik, mivel minden fajnak más az igénye, más növényeket kedvel. Ha területkezelésröl beszélünk, akkor a jószágváltást is előnybe' részesitem. Egy nagylábas jószág után egy-két hét múlva rámén egy juhféle, és nem köll tarra rágatni. / Nagyon jó a 
kecske, rendbe'tartja a legelöt. Sok olyan növényt megeszik (pl. a bokrokat), amit a birka nem.

Nem csak a vegetációra, hanem az állatvilágra is jó hatással van a legeltetés. Ezt a pásztorok is hangsúlyozzák. Ha van egy természetvédelmi szempontból fontos terület, mint a mocsár, ahol rengeteg vízimadár fészkel, akkor odaviszed a jószágot, de az onnantól csak ott legel. Hosszú éveken keresztül csak ott legeltetni, mer' ha fölhagyod a legeltetést, visszanö minden, és semmit nem értél el. / Mégiscsak, szarta, mégiscsak huggyozta, több lett a madár. Az élövilágnak is van egy körforgása, amihez szükségeltetik a jószág.

Az elhanyagolt területek regenerálásánál a lényeg, hogy legeltetve, meg kezelve legyen. / Az a lényege, a jószág. Akkor tisztul, meg visszanyeri eredeti önmagát. I Az egész legeltetésnek a folytonosság lenne a lényege.

\section{Záró gondolatok}

Mint a bevezetőben írtuk, az ENSZ ernyője alatt indult IPBES program párizsi konferenciája volt e cikk ihletője. Az ottani eszmecsere hatására itthon is elindult egy intenzív beszélgetés pásztorok és természetvédelmi szakemberek között. A megbeszéléseken előtérbe helyeződtek azok a témák, amelyek átgondolása időszerüvé vált mind a természetvédelem, mind a pásztorság részéről, a közös együttmúködés és a legelők diverzitásának megőrzése érdekében. Több olyan, törvény által szabályozott kérdésben folynak egyeztetések, amelyek változtatást igényelnek a természetvédelem és a pásztorság szempontjából egyaránt. A pásztorok ökológiai tudása, természetismerete, tapasztalata nagy segítséget nyújthat a felmerült problémák kezelésében.

A megbeszéléseken kérdőívekkel is gyüjtöttünk gondolatokat. Összesen 40 természetvédelmi őrt, felügyelőt, ökológus és botanikus kutatót kérdeztünk meg, hogy milyen érvek szólnak a legeltetéses állattartás, ill. a hagyományos pásztorral történő legeltetés mellett, valamint megkérdeztük, hogy szerintük mi a feladata egy pásztornak a legelőn. A válaszok tanulságosak voltak. A válaszolók 47,5\%a megemlítette, hogy fontos a legeltetés a biodiverzitás megőrzése szempontjából. 30\% említette, hogy van szerepe a pásztorok általi irányított legeltetésnek a természeti értékek fenntartásában. Mindezek ellenére csak 22,5\% jelölte meg a pásztorok feladatának a területkezelést, a gyep megfelelö, fenntartható hasznosítását. Cikkünk fö üzenete, hogy ha szorosabb együttmüködést sikerül kialakítani pásztorok és természetvédők között, az hozzájárulhat a természetvédelem hatékonyságának növekedéséhez (vö. Kis 2011 a, b, Meuret \& Provenza 2014, Babai et al. 2015, Molnár et al. 2016, Vadász et al. 2016). 
Gondolatainkat Fegyver Tibor (társszerző, gulyás) egy versének részletével zárjuk:

Újra legel a sok szürke

Több száz éves múltjával

Az időjárás viszontagságait legyürik.

Olyan ez mint a gulyás

Aki egész életét a gulya mellett leélte

Nagy tisztelet járna neki érte.

Majd felnö új generáció

Ami lassan fogyó

Mert a pásztorságra születni kell

A jószágot meg szeretni!

Köszönetnyilvánítás - Köszönetemet szeretném kinyilvánítani az IPBES-nek, amiért megerősítette bennem a téma feldolgozásának fontosságát. Köszönet Molnár Zsoltnak a cikk szerkezeti összeállításában és a hivatkozásokban nyújtott segítségéért, valamint Balogh Gábornak két pásztorral történt kapcsolatfelvétel elősegítéséért.

\section{Irodalomjegyzék}

Babai, D., Tóth, A., Szentirmai, I., Biró, M., Máté, A., Demeter, L., Szépligeti, M., Varga, A., Molnár, Á., Kun, R. \& Molnár, Zs. (2015): Do conservation and agri-environmental regulations support effectively traditional small-scale farming in East-Central European cultural landscapes? - Biodiv. Conserv. 24: 3305-3327. http://dx.doi.org/10.1007/s10531-015-0971-z

Báldi, A., Batáry, P., \& Kleijn, D. (2013): Effects of grazing and biogeographic regions on grassland biodiversity in Hungary - analysing assemblages of 1200 species. - Agric. Ecosyst. \& Environ. 166: 28-34. http://dx.doi.org/10.1016/j.agee.2012.03.005

Bellon, T. (1996). Beklen. A nagykunsági mezövárosok állattartó gazdálkodása a XVIII-XIX. században. - Karcag város önkormányzata, Karcag.

de Snoo, G. R., Herzon, I., Staats, H., Burton, R. J., Schindler, S., van Dijk, J., Lokhorst, A. M., Bullock, J. M., Lobley, M., Wrbka, T., Schwarz, G. \& Musters, C. J. M. (2013): Toward effective nature conservation on farmland: making farmers matter. - Conserv. Lett. 6: 66-72. http://dx.doi. org/10.1111/j.1755-263X.2012.00296.x

Haraszthy, L. (szerk.) (2014): Natura 2000 fajok és élőhelyek Magyarországon. - Pro Vértes Természetvédelmi Közalapítvány, Csákvár.

Heikkinen, H. I., Sarkki, S. \& Nuttall, M. (2012): Users or producers of ecosystem services? A scenario exercise for integrating conservation and reindeer herding in northeast Finland. - Pastoralism 2: 1-24. http://dx.doi.org/10.1186/2041-7136-2-11 
Kis, J. (2011a): A valamikori legeltetési rend és a pásztorok tudásának lehetőségei a természetvédelmi kezelésekben, Hortobágy térségében. - B.Sc. szakdolgozat, Debreceni Egyetem Természetvédelmi Állattani és Vadgazdálkodási Tanszék, Debrecen.

Kis, J. (2011b): Mit tanulhatnak a pásztorok a természetvédőktől, és mit tanulhatnak a természetvédők a pásztoroktól. - In: Varga, K. \& Kosztyi, B. (szerk.): VII. Magyar Természetvédelmi Konferencia. Program és absztrakt kötet. Magyar Biológiai Társaság, Budapest, $24 \mathrm{p}$.

Kunkovács, L. (2013): Pásztoremberek. - Cser Kiadó, Budapest.

Mapinduzi, A. L., Oba, G., Weladji, R. B. \& Colman, J. E. (2003): Use of indigenous ecological knowledge of the Maasai pastoralists for assessing rangeland biodiversity in Tanzania. - Afr. $J$. Ecol. 41: 329-336. http://dx.doi.org/10.1111/j.1365-2028.2003.00479.x

Meuret, M. \& Provenza, F. D. (2014): The Art \& Science of Shepherding. Tapping the Wisdom of French Herders. - Acres, USA.

Molnár, Zs. (2012): A Hortobágy pásztorszemmel. A puszta növényvilága. - Természetvédelmi Közalapítvány, Debrecen, Hortobágy.

Molnár, Zs. (2014): Perception and Management of Spatio-Temporal Pasture Heterogeneity by Hungarian Herders. - Rangeland Ecol. Manage. 67: 107-118. http://dx.doi.org/10.2111/REMD-13-00082.1

Molnár, Zs., Kis, J., Vadász, Cs., Papp, L., Sándor, I., Béres, S., Sinka, G., Varga, A. (2016): Common and conflicting objectives and practices of herders and nature conservation managers: the need for a conservation herder. - Ecosystem Health Sustain. http://dx.doi.org/10.1002/ehs2.1215

Németh, A. (2016): Az élővilág első, emberiség okozta krízise. - Élet és Tudomány 71: 404-406.

UNESCO-IPBES (2013): The Contribution of Indigenous and Local Knowledge Systems to IPBES: Building Synergies with Science. - Report of International Expert Workshop, Tokyo, 9-11.06.2013. Towards principles and procedures for working with Indigeneous and Local Knowledge systems, 2013. http://unesdoc.unesco.org/images/0022/002252/225242e.pdf

Vadász, Cs., Máté, A., Kun, R., Vadász-Besnyői, V. (2016): Quantifying the diversifying potential of conservation management systems: An evidence-based conceptual model for managing speciesrich grasslands. - Agric. Ecosyst. Environ. http://dx.doi.org/10.1016/j.agee.2016.03.044

Varga, A., Molnár, Zs., Biró, M., Demeter, L., Gellény, K., Miókovics, E., Molnár, Á., Molnár, K., Ujházy, N., Ulicsni, V., Babai, D. (2016): Changing year-round habitat use by extensively herded cattle, sheep and pigs in East-Central Europe between 1940 and 2014: Consequences for conservation management. - Agric. Ecosyst. Environ. in press 


\title{
Herders' traditional knowledge and worldview and their role in protecting biodiversity and ecosystem services
}

\author{
József Kis ${ }^{1}$, Sándor Barta ${ }^{2}$, Lajos Elekes ${ }^{3}$, László Engi ${ }^{4}$, Tibor \\ Fegyver $^{5}$, József Kecskeméti ${ }^{6}$, Levente Lajkó ${ }^{7}$ and János Szabó ${ }^{8}$ \\ ${ }^{1}$ herdsman, H-6625 Fábiánsebestyén, Rózsa Ferenc utca 30, Hungary \\ ${ }^{2}$ herdsman, H-5321 Kunmadaras, Széchenyi u. 7, Hungary \\ ${ }^{3}$ herdsman, H-6767 Ópusztaszer, Rontó szél 173, Hungary \\ ${ }^{4}$ herdsman, H-6728 Szeged, Gyula u. 16, Hungary \\ ${ }^{5}$ herdsman,H-6900 Makó, Járandó u. 14/1, Hugary \\ ${ }^{6}$ shepherd,H-6097 Kunadacs, Peregadacs u. 3, Hungary \\ ${ }^{7}$ shepherd, H-6794 Üllés, Sipos malom 42, Hungary \\ ${ }^{8}$ shepherd, H-4002 Debrecen, Nagy Mihály kert 71, Hungary \\ e-mail:jozsefkis82@gmail.com
}

Traditional herding and conservation management is interdependent. Herders know well their environment, its wildlife, they learn the centuries-old herding skills from their parents and elders, but also from personal experience. The first author (also a herder himself) of the paper interviewed seven herders about their knowledge and understanding of pastures and grazing. Herders utilized sandy, loess and salt steppes. Results show that herders regarded nature as their home, they regulated grazing by partitioning the pasture, and rotational resting of the parts. They had daily and seasonal plans how to utilize the biomass of their pastures to sustain or increase its ecosystem services on the long term. Abandoned areas (with reed and litter) were restored efficiently. These traditional practices are vital also for the protection of biodiversity. The paper was written for those conservationists and researchers, how want to learn more about the role traditional herders and their traditional ecological knowledge could play in maintaining functionally healthy pasture ecosystems. As a herder put it: ,wildlife has a cycle, and livestock is needed for this cycle”.

Keywords: traditional herding, partitioning of pastures, conservation management, traditional ecological knowledge, science of herding 